\title{
Stability and activity of an Enterobacter aerogenes-specific bacteriophage under simulated gastro-intestinal conditions
}

Received: 24 October 2003 / Revised: 30 January 2004 / Accepted: 30 January 2004 / Published online: 26 February 2004

(C) Springer-Verlag 2004

\begin{abstract}
A bacteriophage, designated UZ1 and showing lytic activity against a clinically important strain (BE1) of Enterobacter aerogenes was isolated from hospital sewage. The stability and lytic activity against this strain under simulated gastro-intestinal conditions was evaluated. After addition of bacteriophage UZ1 to a liquid feed at gastric $\mathrm{pH} 2$, the phage was immediately inactivated and could not be recovered. However, by use of an antacid to neutralize stomach acidity, no significant changes in phage titer were observed after $2 \mathrm{~h}$ incubation at $37^{\circ} \mathrm{C}$. After supplementing pancreatic juice and further incubation for $4 \mathrm{~h}$, the phage titer remained stable. The persistence of UZ1 in a mixed microbial ecosystem that was representative for the large intestine was monitored using an in vitro simulation of the human intestinal microbial ecosystem. A pulse administration of bacteriophage UZ1 at a concentration of $10^{5}$ plaque-forming units (PFU)/ml to reactor 3 (which simulates the ascending colon) showed that, in the absence of the host, bacteriophage UZ1 persisted for 13 days in the simulated colon, while the theoretical washout was calculated at 16 days. To assess its lytic activity in an intestinal microbial ecosystem, a green fluorescent protein $(g f p)$-labeled $E$. aerogenes BE1 strain was constructed and $g f p$-specific primers were designed in order to quantify the host strain using real-time PCR. It was observed that bacteriophage UZ1 was able to replicate and showed lytic activity against $E$. aerogenes $\mathrm{BE} 1 / g f p$ in an intestinal microbial ecosystem. Indeed, after $17 \mathrm{~h}$ a $2 \log$ unit reduction of $E$. aerogenes $\mathrm{BE} 1 / g f p$ was
\end{abstract}

K. Verthé $\cdot$ S. Possemiers $\cdot$ N. Boon $\cdot$ W. Verstraete $(\bowtie)$ LabMET, Ghent University,

Coupure Links 653,

9000 Ghent, Belgium

e-mail: Willy.Verstraete@UGent.be

Tel.: +32-9-2645976

Fax: $+32-9-2646248$

M. Vaneechoutte

Department of Clinical Chemistry, Microbiology and

Immunology, Ghent University,

Coupure Links 653,

9000 Ghent, Belgium measured as compared with the assay without bacteriophage UZ1, while the phage titer increased by $2 \log$ units at an initial multiplicity of infection of $0.07 \mathrm{PFU} /$ colonyforming unit. This is the first report of an in vitro model to study bacteriophage activity in the complex intestinal microbial community.

\section{Introduction}

Bacteriophages (phages), viruses with a bacterial host, are ubiquitous and highly diverse. They have been isolated from a wide variety of environments, including seawater (Borsheim 1993), soil (Ashelford et al. 2003), sewage (Ewert and Paynter 1980), food products (Gautier et al. 1995; Josephsen and Neve 1998; Yoon et al. 2002), and feces (Furuse et al. 1983). The property of phages to infect and lyse bacterial cells led to the therapeutic use of bacteriophages, the so-called phage therapy. The first report of phage therapy was by Felix d'Herelle in 1919 to treat a patient with dysentery (Summers 1999). With the advent and success of antibiotics, phage therapy passed into oblivion. However, in the former Soviet Union the therapeutic use of bacteriophages was further developed, which resulted in a number of reports on the use of phage therapy in English literature (Slopek et al. 1987; Chanishvili et al. 2001; Sulakvelidze et al. 2001). Experiments on laboratory animals and the use of phage therapy in veterinary medicine have also been reported (Smith and Huggins 1983; Berchieri et al. 1991; Soothill 1992; Ramesh et al. 1999; Biswas et al. 2002).

In contrast, the human intestinal tract has been extensively studied and several in vitro systems have been developed (Molly et al. 1993; Hack and Selenka 1996; Macfarlane et al. 1998; Minekus et al. 1999; De Boever et al. 2001). In vitro models offer defined experimental conditions and easy sampling. Also, the lack of ethical constraints when using in vitro model systems over human or animal subjects is an advantage. The simulation of the human intestinal microbial ecosys- 
tem (SHIME) is a five-stage reactor developed by Molly et al. (1993) and optimized by De Boever et al. (2001).

As a model pathogen in this study, a clinical isolate of Enterobacter aerogenes, strain BE1, was used. Species of Enterobacter are opportunistic pathogens and rarely cause disease in the otherwise healthy individual. Most of these organisms are innately resistant to conventional antimicrobial agents and have the ability to rapidly develop resistance to newer agents. Among the Enterobacter genus, E. cloacae and E. aerogenes are the two species most frequently isolated from clinical samples; and these organisms belong to the normal digestive microbiota (Sanders and Sanders 1997). Most nosocomial Enterobacter infections appear to arise indigenous from a previously colonized site in the patient (Flynn et al. 1987; Galili et al. 1992; Fryklund et al. 1994). Colonization of the gastro-intestinal tract and other body sites with Enterobacter spp frequently occurs in the seriously ill patient, especially after prior antibiotic therapy (Gaston 1988; Falkiner 1992). From a survey in Belgian hospitals from 1996 to 1998, the data collected suggested a nationwide dissemination of two epidemic multiresistant E. aerogenes strains (BE1, BE2) in Belgium. The BE1 type was indistinguishable from a previously described epidemic strain in France (De Gheldre et al. 2001). Those facts indicate that the number of clinically important strains throughout Europe may be rather limited such that development of a controlling strategy for nosocomial $E$. aerogenes infections by host-specific bacteriophages may be feasible.

The objective of the present study was to develop an in vitro model to investigate bacteriophage stability and activity under gastro-intestinal conditions. The model consists of a bacteriophage (UZ1) and its host, a clinical isolate of $E$. aerogenes. Different aspects affecting bacteriophage stability during transit through the gastro-intestinal tract were evaluated, i.e. resistance to stomach acidity, bile, and pancreatin. Persistence in an intestinal microbial ecosystem was determined using the SHIME. Bacteriophage replication and host titer were monitored in a microbial community representative of that in the large intestine. This is the first report of an in vitro model study on bacteriophage activity in the complex microbial intestinal community.

\section{Materials and methods}

\section{Bacteriophage UZ1}

Bacteriophage UZ1 was isolated from hospital sewage (University Hospital, Ghent, Belgium), using an enrichment procedure. Sewage samples were centrifuged for $5 \mathrm{~min}$ at $10,000 \mathrm{~g}$ and the supernatant was filter-sterilized $(0.22 \mu \mathrm{m})$. From the supernatant, aliquots of $8 \mathrm{ml}$ were supplemented with $1 \mathrm{ml}$ of $10 \times \mathrm{LB}$ medium, $1 \mathrm{ml}$ of a mid-log phase culture of $E$. aerogenes $\mathrm{BE} 1$, and incubated on a shaker for $4 \mathrm{~h}$ at $37{ }^{\circ} \mathrm{C}$. LB medium composition was (per liter): $10 \mathrm{~g}$ trypton (Applichem, Darmstadt, Germany), $5 \mathrm{~g}$ yeast extract (Applichem), and $\mathrm{NaCl}$. After enrichment, samples were centrifuged for $5 \mathrm{~min}$ at $10,000 \mathrm{~g}$ and the supernatant was filter-sterilized $(0.22 \mu \mathrm{m})$. To detect phages, the soft agar layer method described by
Adams (1959) was applied, using serially dilutions of the supernatant in $\mathrm{SM}$ medium $(50 \mathrm{mM}$ Tris- $\mathrm{HCl}, \mathrm{pH} 7.5,100 \mathrm{mM} \mathrm{NaCl}$, $10 \mathrm{mM} \mathrm{MgSO}$, $0.01 \%$ gelatin). In brief, $100 \mu 1$ of serially diluted supernatant was mixed with $400 \mu 1$ of a mid-log phase $E$. aerogenes BE1 culture and $2.5 \mathrm{ml}$ of $0.5 \%$ agar (Federa, Brussels, Belgium). The mixture was poured over a Petri dish with LB agar (LB medium supplemented with $15 \mathrm{~g}$ agar/l) and incubated for $16 \mathrm{~h}$ at $37{ }^{\circ} \mathrm{C}$. Single plaques were picked and isolated again three times to ensure pure phage strains.

To prepare phage stock, a single plaque was diluted in $500 \mu \mathrm{l}$ of SM medium and the soft agar layer method was used as described above, using $100 \mu \mathrm{l}$ of the diluted plaque. Soft agar layers were removed from plates and diluted in $10 \mathrm{ml}$ of SM medium. Phages were separated by centrifugation for $10 \mathrm{~min}$ at $10,000 \mathrm{~g}$ and filtersterilized $(0.22 \mu \mathrm{m})$.

For the determination of phage titers, serial dilutions were plated using the soft agar layer technique, as described above.

\section{Restriction analysis and transmission electron microscopy}

Bacteriophage DNA was extracted according to Hambly et al (2001). Restriction analysis and gel electrophoresis of bacteriophage DNA were executed as described by Sambrook and Russell (2001). The restriction enzymes used were DraI, MspI, and EcoRI (Amersham Biosciences, Roosendaal, The Netherlands).

For transmission electron microscopy, bacteriophages were applied to copper-mesh grids and negatively stained with $2 \%$ uranyl acetate.

Host-range of bacteriophage UZ1

The host-range of bacteriophage UZ1 was determined by spotting phage UZ1 on bacterial lanes of $E$. aerogenes BE1 and five other strains (E. aerogenes BE2, E. aerogenes ATCC 13048, E. cloacae LM W011, Escherichia coli ESBL 111, E. coli ESBL 112). After overnight incubation at $37{ }^{\circ} \mathrm{C}$, bacterial lanes were screened for plaque formation. The clinical isolates were supplied from the collection of the Department of Clinical Chemistry, Microbiology and Immunology (Ghent University, Belgium).

Effect of $\mathrm{pH}$, bile salts, and pancreatin on bacteriophage UZ1

The effect of $\mathrm{pH}$ was examined by diluting phage UZ1 to a final concentration of $6.2 \pm 0.3 \times 10^{5}$ plaque-forming units $(\mathrm{PFU}) / \mathrm{ml}$ in $\mathrm{SM}$ medium set to different $\mathrm{pH}$ levels ( $\mathrm{pH} 2,4,6,7,9)$ with $1 \mathrm{~N} \mathrm{NaOH}$ or $1 \mathrm{~N} \mathrm{HCl}$. Samples were taken at the start of the experiment and after $1 \mathrm{~h}$ of incubation at $37^{\circ} \mathrm{C}$. Phage titers were determined by the soft agar layer technique, as described above.

The effect of antacid, bile salts and pancreatin on bacteriophage UZ1 was studied as follows. In an Erlenmeyer flask (500 $\mathrm{ml}$ vol.), $1 \mathrm{ml}$ of a phage stock at $8 \log \mathrm{PFU} / \mathrm{ml}$ was added to $140 \mathrm{ml}$ of a liquid reactor feed. The feed composition was identical to the SHIME reactor feed (per liter): $1 \mathrm{~g}$ arabinogalactan, $2 \mathrm{~g}$ pectin, $1 \mathrm{~g}$ xylan, $3 \mathrm{~g}$ potato starch, $0.4 \mathrm{~g}$ glucose, $3 \mathrm{~g}$ yeast extract, $1 \mathrm{~g}$ peptone, $4 \mathrm{~g}$ mucin, and $0.5 \mathrm{~g}$ cystein. The feed was autoclaved and the $\mathrm{pH}$ of the feed was set to 2 with $6 \mathrm{~N} \mathrm{HCl}$. For the treatment with antacid, $1.75 \mathrm{~g} \mathrm{NaHCO}_{3}$ was added prior to inoculation with phage. After incubation for $2 \mathrm{~h}$ at $37^{\circ} \mathrm{C}$ with shaking, $60 \mathrm{ml}$ of pancreatic fluid was supplemented consisting of (per liter): $1.5 \mathrm{~g}$ pancreatin (Sigma), 6 g bile (oxgall; Difco), and $12.5 \mathrm{~g} \mathrm{NaHCO}_{3}$. Erlenmeyers were incubated for another $4 \mathrm{~h}$ at $37{ }^{\circ} \mathrm{C}$ with shaking. Samples $(1 \mathrm{ml})$ were taken and $\mathrm{pH}$ was measured at the start, after $2 \mathrm{~h}$, and at the end of the incubation. Samples were centrifuged for $5 \mathrm{~min}$ at $10,000 \mathrm{~g}$ and the supernatant was used for the determination of phage titer as described above. 


\section{E. aerogenes $\mathrm{BE} 1 / g f p$}

Marking with gfp

The genes for the green fluorescent protein $(g f p)$ fluorochrome and kanamycin resistance were inserted into the chromosome of $E$. aerogenes BE1. This was done by means of a biparental mating

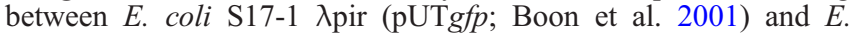
aerogenes $\mathrm{BE} 1$, with selection on LB plates with tetracyclin $(20 \mathrm{mg} /$ 1) and kanamycin $(50 \mathrm{mg} / \mathrm{l})$. The obtained marked cells were selected on their GFP fluorescence (excitation at 396/476 nm, emission at $508 \mathrm{~nm}$ ) by a Dark Reader illuminator (Clare Chemical Research, Denver, Colo.). The infectivity of bacteriophage UZ1 was not affected after labeling E. aerogenes BE1 with the $g f p$ gene.

\section{Detection and quantification of the gfp gene}

Total DNA extractions from bacterial culture of E. aerogenes BE1/ $g f p$ and samples from the lytic activity assays were performed using the method adapted from Griffiths et al. (2000) and Kowalchuck et al. (1998), as described by Boon et al. (2002). The primers for realtime amplification of the Aequorea victoria $g f p$ gene (GenBank accession number U73901.1) were constructed by the use of Primer Express ver. 2.0 (Applied Biosystems, Nieuwekerk a/d Ijssel, The Netherlands). The specificity of the designed primers was checked using the BLAST server of the National Center for Biotechnology Information, using the BLAST algorithm (Altschul et al. 1997). The forward primer, GFP-F-272-293 (3'-GCCATGCCAGAAGGTTATGTTC-5'; positions 272-293) and reverse primer GFP-R-356332 (3'-CAAACTTGACTTCAGCTCTGGTCTT-5'; positions 332356) amplified a PCR fragment of $85 \mathrm{bp}$.

Real-time quantitative PCR was performed using an ABI Prism SDS 7000 instrument (PE Applied Biosystems, Nieuwerkerk a/d Ijssel, The Netherlands). All reagents used to perform real-time PCR detection were purchased from Applied Biosystems. The amplification reactions were carried out with Sybr Green PCR master mix containing AmpliTaq Gold DNA polymerase, AmpErase uracil- $N$ glycosylase, Sybr GreenI, deoxynucleoside triphosphates with dUTP, and passive reference and optimized buffer components. The final concentrations of each oligonucleotide in the PCR mixture were $300 \mathrm{nM}$. The total volume of the PCR mixture was $25 \mu \mathrm{l}$, including $1 \mu \mathrm{l}$ of DNA template, in MicroAmp Optical 96-well reaction plates with optical caps, and the PCR was carried out according to the instructions of the manufacturer. The PCR temperature program was as follows: $50{ }^{\circ} \mathrm{C}$ for 2 min and $95{ }^{\circ} \mathrm{C}$ for $10 \mathrm{~min}$, followed by 40 cycles of $95^{\circ} \mathrm{C}$ for $15 \mathrm{~s}$, and $60{ }^{\circ} \mathrm{C}$ for $1 \mathrm{~min}$. The concentrations of the primers and probes were optimized as described in the TaqMan universal PCR master mix protocol (Applied Biosystems).

The increase in emission intensity was measured during the amplification reaction by the ABI PRISM 7000 sequence detection system (SDS). Data acquisition and analysis were handled by ABI PRISM 7000 SDS software ver. 1.0 (Applied Biosystems). Briefly, a threshold is assigned to the log phase of product accumulation. The point at which the threshold crosses the amplification curve is defined as a cycle threshold value, termed $C_{\mathrm{T}}$. With increasing target quantity in the PCRs, the $C_{\mathrm{T}}$ value decreases linearly and thus $C_{\mathrm{T}}$ values can be used as quantitative measurements of the input target amount (Heid et al. 1996).

The comparative $C_{\mathrm{T}}$ method was used for quantitative analyses. Standard curves were constructed after real-time PCR amplification of DNA extracts of different $E$. aerogenes BE1/gfp cell numbers $(n=4)$ ranging from $5.3 \times 10^{7}$ to $5.3 \times 10^{4}$ colony-forming units (CFU)/ well. The $R^{2}$ value was greater than 0.99 for the standard curves and a slope of -3.67 was generated. Based on the standard curve, the exact number of $E$. aerogenes BE1/gfp cells in the DNA extracts could be determined

\section{Simulator of the human intestinal microbial ecosystem}

The SHIME reactor setup was based on the adult SHIME (Molly et al. 1993; De Boever et al. 2001). In brief, the SHIME was designed to maintain a microbial community that is representative of that in the human intestinal system. The SHIME consisted of five sequential reactors that represent the different parts of the intestinal tract: stomach and duodenum (reactor 1), jejunum and ileum (reactor 2), ascending colon (reactor 3), transverse colon (reactor 4), and descending colon (reactor 5). The first two reactors were of the fill-and-draw principle, while the last three were continuous stirred reactors with $\mathrm{pH}$ control. The overall residence time of the last three reactors, simulating the large intestine, was $76 \mathrm{~h}$. The temperature of the system was kept at $37^{\circ} \mathrm{C}$ by a thermostat and the system was kept anaerobic by flushing with $\mathrm{N}_{2}$ for 15 min every day. Inoculum preparation and reactor start-up were as described by De Boever et al. (2001).

Persistence of bacteriophage UZ1 in the SHIME

A single dose of phage UZ1 was administrated to reactor 3 to a final concentration of $1.0 \times 10^{5} \mathrm{PFU} / \mathrm{ml}$. Samples were taken daily from reactors 3,4 , and 5 , centrifuged for $5 \mathrm{~min}$ at $10,000 \mathrm{~g}$, and filtersterilized. Phage titer was determined by the soft agar layer technique. The theoretical washout of inert particles was calculated using a first-order kinetics model: $X_{t}=X_{0} \times e^{-k t}$, where $X_{t}$ is the phage concentration at time $t, X_{0}$ is the initial phage concentration, and $k$ is determined by [(volume of feed/day)/volume of reactor 3].

Lytic activity assay

Experiments in triplicate were conducted in 100-ml penicillin bottles incubated at $37^{\circ} \mathrm{C}$ for $17 \mathrm{~h}$. For lytic activity assays with SHIME suspension, the reactor content was removed from reactor 5 (descending colon) and 50-ml aliquots were transferred to penicillin bottles. E. aerogenes BE1/gfp and phage UZ1 were added to the penicillin bottles at the start of the experiment at final concentrations of $8.6 \pm 0.89 \times 10^{5} \mathrm{CFU} / \mathrm{ml}$ and $5.8 \pm 1.1 \times 10^{4} \mathrm{PFU} / \mathrm{ml}$, respectively. Phage titers were determined by the soft agar layer technique and $E$. aerogenes $\mathrm{BE} 1 / g f p$ concentrations were determined by real-time PCR, using primers specific for the $g f p$ gene sequence.

\section{Results}

Host-range of bacteriophage UZ1

Phage UZ1 was found to be infective only for $E$. aerogenes BE1 LMG 22092. No plaque formation was observed on the other strains tested: E. aerogenes BE2 LMG 22093, E. aerogenes ATCC 13048, E. cloacae LM W011 LMG 22094, E. coli ESBL 111 LMG 22095, and E. coli ESBL 112 LMG 22096.

\section{Tentative classification of bacteriophage UZ1}

After restriction of phage DNA with DraI, the size of the major bands were approximately $23,000 \mathrm{bp}, 7,000 \mathrm{bp}$, and 4,000 bp (Fig. 1). Phage DNA could not be restricted with EcoRI or MspI. Transmission electron microscopy revealed phage particles having an isometric head with a diameter of approximately $65 \mathrm{~nm}$ and a short non- 
contractile tail (Fig. 2). These morphological properties and the estimated genome size of at least $34 \mathrm{~kb}$ correspond to the T7-like phages of the genus Podovirida (Order: Caudovirales).

Effect of $\mathrm{pH}$, bile salts, and pancreatin on bacteriophage UZ1

After $1 \mathrm{~h}$ incubation at $37^{\circ} \mathrm{C}$ at different $\mathrm{pH}$ levels, there were no significant differences $(P>0.05)$ between the initial phage titer of $6.2 \pm 0.3 \times 10^{5} \mathrm{PFU} / \mathrm{ml}$ and the phage

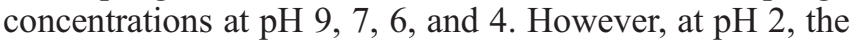
concentration of bacteriophage UZ1 dropped below the detection limit $\left(1.0 \times 10^{1} \mathrm{PFU} / \mathrm{ml}\right)$ immediately after the addition of phage UZ1.

The effect of gastric acidity, bile salts, and pancreatin on bacteriophage UZ1 after addition of antacid (1.75 g $\mathrm{NaHCO}_{3}$ ) is given in Table 1 . In the control reactors, phages were immediately inactivated and no phages could be detected throughout the incubation. However, in the reactors with antacid added prior to the administration of phage UZ1, there was no significant effect on the phage concentration during the $6 \mathrm{~h}$ of incubation.

Fig. 1 DraI restriction analysis of DNA from phage UZ1. $M$ Lambda/HindIII marker. DNA fragment size is indicated at the right

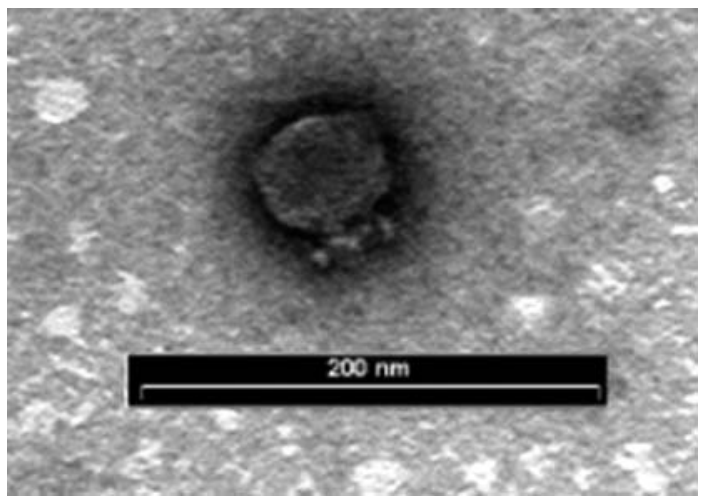

Fig. 2 Transmission electron microscopy of bacteriophage UZ1. Phage particles had an isometric head with a diameter of approximately $65 \mathrm{~nm}$ with a short non-contractile tail

Table 1 Effect of stomach acidity, bile salts, and pancreatin on the stability of phage UZ1. By the addition of pancreatic juice after $2 \mathrm{~h}$ of incubation at $37^{\circ} \mathrm{C}$, the reactor volume increased from $140 \mathrm{ml}$ to $200 \mathrm{ml}$ and therefore the total number of plaque-forming units (PFU) per reactor is given. For each treatment, antacid $(1.75 \mathrm{~g}$ $\mathrm{NaHCO}_{3}$ ) was added prior to the addition of bacteriophage UZ1 $(1 \mathrm{ml}$ of $8.4 \pm 0.1 \log \mathrm{PFU} / \mathrm{ml})$

\begin{tabular}{llll}
\hline & $\begin{array}{l}\text { Time } \\
(\mathrm{h})\end{array}$ & $\mathrm{pH}$ & $\begin{array}{l}\text { Phage UZ1 } \\
(\log \text { PFU/reactor })\end{array}$ \\
\hline Treatment & 0 & $6.62 \pm 0.04$ & $8.3 \pm 0.06$ \\
Control & 0 & $2.03 \pm 0.02$ & $<3.1^{\mathrm{a}}$ \\
Treatment & 2 & $6.67 \pm 0.04$ & $8.3 \pm 0.03$ \\
Control & 2 & $2.04 \pm 0.01$ & $<3.1^{\mathrm{a}}$ \\
Treatment & 6 & $8.58 \pm 0.12$ & $8.2 \pm 0.05$ \\
Control & 6 & $7.72 \pm 0.05$ & $<3.3^{\mathrm{a}}$ \\
\hline
\end{tabular}

${ }^{\mathrm{a}}$ No phages detected, $<1 \mathrm{PFU} / 100 \mu 1$

\section{Persistence of bacteriophage UZ1 in the SHIME}

$23130 \mathrm{bp}$ The persistence of bacteriophage UZ1 in the simulated large intestine (reactors 3, 4, and 5; Fig. 3) was evaluated in the absence of the host, E. aerogenes BE1, and the theoretical washout was calculated. Before addition of the phage to the system, samples from the colon reactors were taken and screened for the presence of phages infective for E. aerogenes BE1. Since the soft agar layer technique detected no such phages, it can be assumed that the phages detected during the subsequent experiment were those added, i.e. phage UZ1. The detection limit of this experiment was $1.0 \times 10^{1} \mathrm{PFU} / \mathrm{ml}$. Phage UZ1 could be detected for 7 days in reactor 3 , while the calculated washout would have reached the detection limit after 9 days. For reactor 4, phage UZ1 was detectable until day 12 , while the theoretical washout was 14 days. Phage UZ1 stayed detectable in reactor 5 for up to 13 days, while calculated washout reached the detection limit on day 16 . 
Fig. 3 Persistence of phage UZ1 (plaque-forming units, $P F U)$ in the colon reactors $(R 3$, $R 4, R 5)$ of the simulation of the human intestinal microbial ecosystem (SHIME). The calculated theoretical washout (R3theor, R4theor, R5theor) is indicated by dotted lines. A single dose $\left(1.0 \times 10^{5} \mathrm{PFU} / \mathrm{ml}\right)$ of phage UZ1 was added to reactor 3 at day 1 . The detection limit was $1.0 \times 10^{1} \mathrm{PFU} / \mathrm{ml}$. Bacteriophage UZ1 was detectable up to days 7,12 , and 13 in reactors 3,4 , and 5 , respectively. Theoretical washout reached the detection limit after 9, 14, and 16 days in reactors 3,4 , and 5 , respectively. $d$ Days

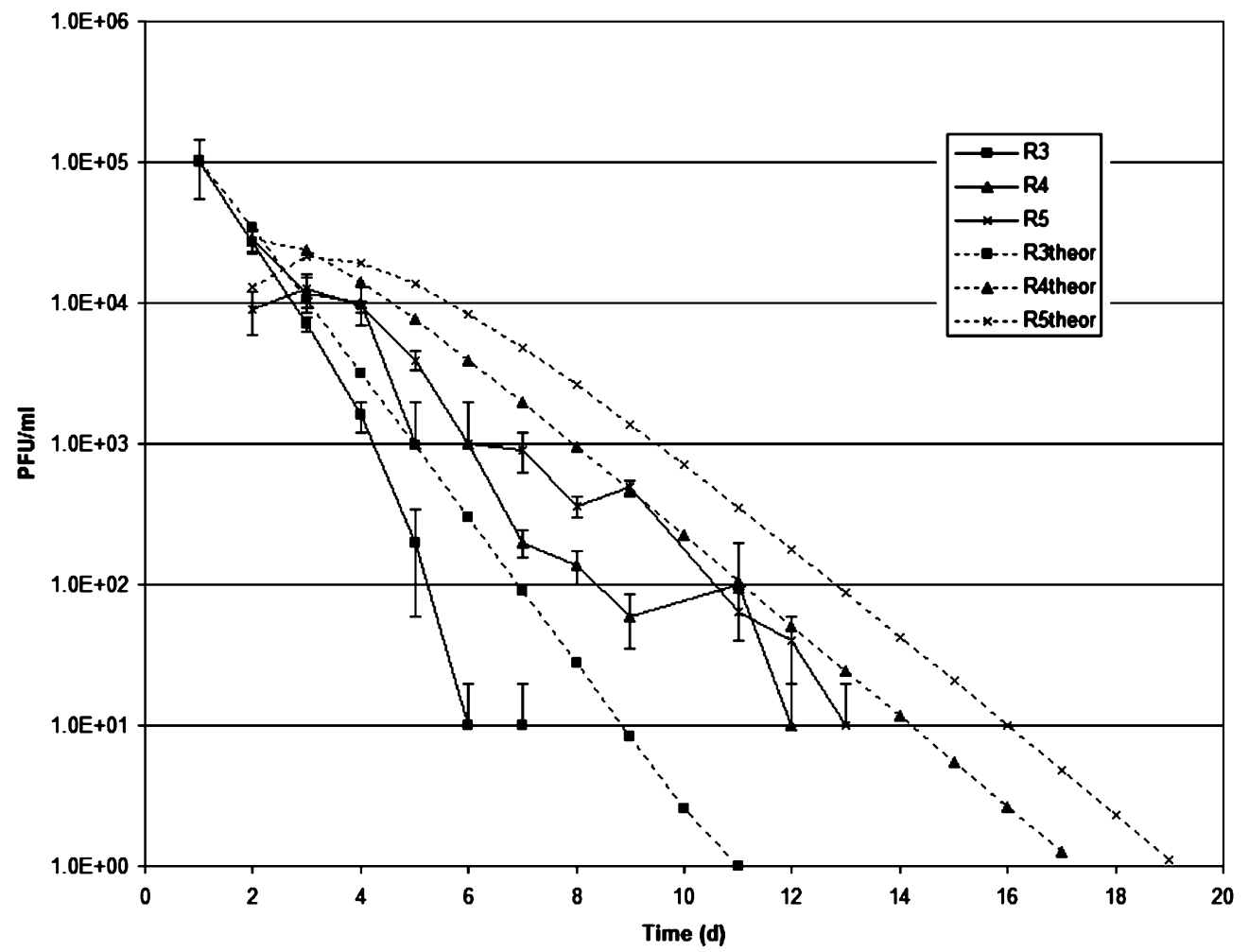

Lytic activity assay

Lytic activity of bacteriophage UZ1 against E. aerogenes $\mathrm{BE} 1 / g f p$ was determined both in a monoculture with LB medium and in the presence of the microbiota from the SHIME. Results are presented in Fig. 4. In the control assay with phage UZ1, but without $E$. aerogenes $\mathrm{BE} 1 / g f p$, a limited inactivation of the phage was measured. Phage concentrations dropped from $5.8 \pm 0.1 \times 10^{4} \mathrm{PFU} / \mathrm{ml}$ to 2.0 $\pm 0.1 \times 10^{4} \mathrm{PFU} / \mathrm{ml}$ for the assay with LB medium and 5.0 $\pm 0.7 \times 10^{3} \mathrm{PFU} / \mathrm{ml}$ in the SHIME suspension. In the control assay with $E$. aerogenes BE1/gfp, but without phage UZ1, an increase was detected from $8.6 \pm 0.9 \times 10^{5} \mathrm{CFU} / \mathrm{ml}$ to 1.1 $\pm 0.1 \times 10^{8} \mathrm{CFU} / \mathrm{ml}$ in the monoculture with LB medium and $6.9 \pm 1.4 \times 10^{6} \mathrm{CFU} / \mathrm{ml}$ in the assay harboring a SHIME microbial community. In the two assays with both phage UZ1 and strain BE1/gfp, bacteriophage UZ1 was able to replicate and the titer of strain BE1/gfp was below the initial level at the start of the experiment. In the assay with $\mathrm{LB}$ medium, the final concentration of E. aerogenes BE1/ $g f p$ was $2.8 \pm 0.6 \times 10^{5} \mathrm{CFU} / \mathrm{ml}$, while in the assay with the SHIME suspension, the final concentration dropped to 5.9 $\pm 1.2 \times 10^{4} \mathrm{CFU} / \mathrm{ml}$. Interestingly, although the phage titer in the assay with LB was higher than in the assay with the SHIME suspension, $1.4 \pm 0.1 \times 10^{8} \quad \mathrm{PFU} / \mathrm{ml}$ and 7.4 $\pm 0.8 \times 10^{6} \mathrm{PFU} / \mathrm{ml}$, respectively, the lytic effect in the SHIME suspension was higher than in the LB medium.

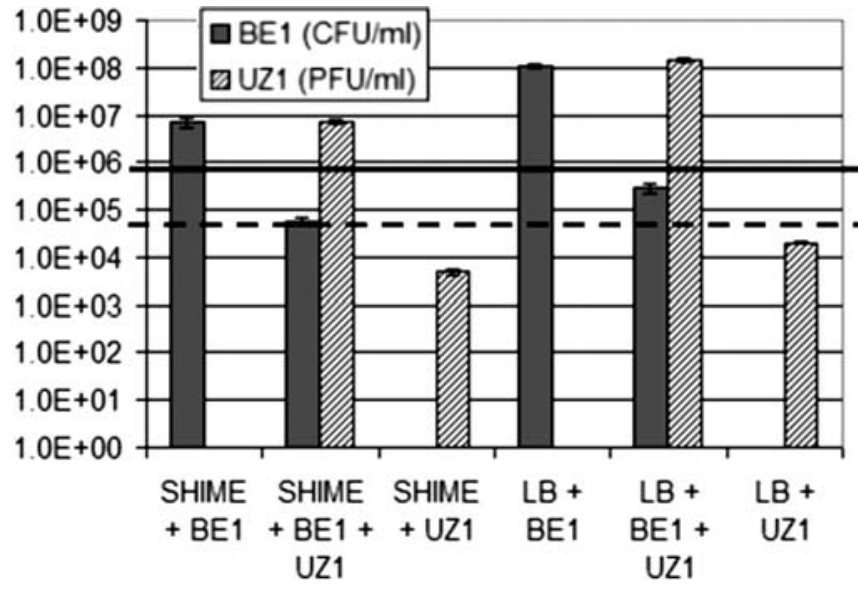

Fig. 4 Lytic activity assays were executed in LB medium with a monoculture of Enterobacter aerogenes BE1/gfp or a SHIME suspension harboring a complex microbial ecosystem. E. aerogenes $\mathrm{BE} 1 / g f p(\mathrm{BE} 1)$ and phage UZ1 were added to final concentrations of $8.6 \pm 0.89 \times 10^{5} \mathrm{CFU} / \mathrm{ml}$ (indicated by the solid line) and 5.8 $\pm 1.1 \times 10^{4} \mathrm{PFU} / \mathrm{ml}$ (indicated by the dotted line), respectively. The multiplicity of infection was 0.07 PFU/CFU

\section{Discussion}

To our knowledge, this is the first report of a host-specific bacteriophage infecting E. aerogenes. Phage UZ1 was found to be infective only for the E. aerogenes strain BE1. It is possible that the isolation and propagation procedures had an influence on the very narrow host-range of phage UZ1. Phage UZ1 was isolated using an enrichment procedure, reisolated three times and further propagated on a single host, $E$. aerogenes BE1. Jensen et al. (1998) 
observed that the frequency with which broad-host-range bacteriophages are isolated is increased by the use of multiple-host enrichment protocols and that single-host methods result in selection for narrow-host-range bacteriophages. The narrow-host-range of phage UZ1, limited to $E$. aerogenes $\mathrm{BE} 1$, is also reflected in the fact that there was no increase in phage titer in the lytic activity assay containing SHIME suspension without the host strain.

In contrast to antibiotics which have a broad-range bactericidal effect, the effect of host-specific bacteriophages on the commensal microbiota is very focused and chances of developing secondary infections are avoided (Chernomordik 1989; Sulakvelidze et al. 2001). A study by De Gheldre et al. (2001) in Belgian hospitals revealed that $E$. aerogenes infections could be assigned to a limited number of strains, since $74 \%$ of all the isolated strains were identified as E. aerogenes strains BE1 or BE2 (De Gheldre et al. 2001). Other studies also confirmed that nosocomial infections in many cases originate from a single (multiresistant) clone with a regional spread (Jalaluddin et al. 1998; Mammeri et al. 2001). These observations point to the potential of therapeutic use of phage UZ1 against $E$. aerogenes BE1 infections.

In the development of the model system in this work, propagation of the phage can be assumed to be solely due to the lytic activity on a single host strain, namely the $g f p$ labeled E. aerogenes $\mathrm{BE} 1$. In this context, comparison with lytic activity in monoculture systems is relevant. The labeling with the $g f p$ gene and the development of $g f p$ specific primers allowed real-time PCR quantification of $E$. aerogenes $\mathrm{BE} 1 / g f p$ in the complex gastro-intestinal microbial community. The marking of bacteria with the $g f p$ gene is widely used in bacteriology and numerous $g f p$ labeled strains are available. Therefore, the use of realtime PCR for the quantification of $g f p$-labeled strains, as presented in this study, can be expanded to other $g f p$ labeled strains and different complex ecosystems.

Figure 4 illustrates that there is more proliferation of phage UZ1 in the lytic activity assay with LB medium than in the SHIME suspension. The monoculture in LB medium offers high nutrient levels for optimal growth of the bacterial strain, resulting in more effective phage replication, as they employ the host's cellular machinery (Middelboe 2000). In the treatment with SHIME suspension, a lower energy level of the host can be expected, due to medium composition and competition with other species. Also, the presence of non-host material of physical or biological origin interfering with the attachment of the phage to its host can be the cause of the lower phage replication. The final lytic effect is the result of two related processes, i.e. bacterial growth rate and phage replication. Although there was more phage replication in the E. aerogenes BE1/gfp culture in LB medium, the observed lytic effect was more pronounced in the reactor with the SHIME suspension. These results were obtained within the limited time frame of the lytic activity assays and at a multiplicity of infection (MOI) of only $0.07 \mathrm{PFU} /$ CFU. For therapeutic applications, a higher MOI is favorable and could be achieved as phage stock solutions of the order of $10^{9} \mathrm{PFU} / \mathrm{ml}$ can be produced.

The acidity of the stomach forms a major barrier when applying phages by oral administration. Phage UZ1 was stable in the range $\mathrm{pH} 4-9$. At $\mathrm{pH} 2$, there was immediate and irreversible inactivation of the phage. Slopek et al. (1983) describe the use of antacid when administering phages orally. Indeed, the use of an antacid like $\mathrm{NaHCO}_{3}$ proved to be very effective in neutralizing the stomach acidity and no significant effects of bile salts and pancreatin were observed. Therefore, the transfer of phages through the stomach should be designed in a way which protects the phages against the stomach acidity. Once the phages arrive in the small and large intestine, it can be expected that they adequately withstand the ambient chemical and enzymatic conditions.

Although phage UZ1 persisted not as long in reactor 3 as calculated for the washout of inert particles, it stayed detectable in the system for 13 days, while the calculated washout reached the detection limit after 16 days. This implies that phage UZ1 is relatively resistant to intestinal conditions but is washed out of this environment in the absence of the host. There was also some inactivation observed in the lytic activity assays, where phage UZ1 was more inactivated in the presence of the SHIME suspension, compared with the reactor with only LB medium. Interaction with non-host material and adsorption onto the matrix are plausible causes for these observations.

The SHIME, like other similar in vitro simulators, is a valuable tool for studying microbiological processes in the gastro-intestinal system. Until now, interactions with the human host (like cellular transport mechanisms or the immune system) were not incorporated in these in vitro models. With respect to bacteriophages, it is not clear whether bacteriophages are able to pass the human luminal barrier. A few studies on laboratory animals suggest that phages enter the bloodstream after oral administration within 2-4 h and that they could be found in the internal organs like liver, spleen, kidney, etc. (Bogovazova et al. 1991, 1992). The development of neutralizing antibodies after the administration of phages to humans is documented (Kucharewicz-Krukowska and Slopek 1987). These antibodies could reduce the effectiveness of phage replication. Because the kinetics of bacteriophage replication are much faster than the development of phage-neutralizing antibodies, this probably will have a limited effect, at least in the short term (Sulakvelidze et al. 2001).

In conclusion, we developed a model system to study bacteriophage persistence and lytic activity under simulated intestinal conditions. Bacteriophage UZ1 persisted for a prolonged period in reactors simulating the different parts of the large intestine. Furthermore, lytic activity assays showed proliferation of the bacteriophage; and the concentration of the $g f p$-labeled host strain could be quantified. The SHIME model was found to be a valuable tool for research in the field of phage ecology and putative phage therapy. 
Acknowledgements This research was funded by a doctoral fellowship (11187) of the Flemish Institute for the promotion of Scientific-Technological Research in the Industry (IWT) and a doctoral fellowship of the Special Research Fund (BOF) of Ghent University. The experiments in this study comply with the current laws of the country in which they were performed. Transmission electron microscopy was done by Dr. Jan Mast (Veterinary and Agrochemical Research Centre, Brussels, Belgium). We thank Kurt Sys for the assistance with the calculations and thank Bram Sercu, Sylvie Seurinck, and Vanessa Vermeirsen for critically reading the manuscript.

\section{References}

Adams MH (1959) Bacteriophages. Interscience, New York

Altschul SF, Madden TL, Schaffer AA, Zhang JH, Zhang Z, Miller W, Lipman DJ (1997) Gapped BLAST and PSI-BLAST: a new generation of protein database search programs. Nucleic Acids Res 25:3389-3402

Ashelford KE, Day MJ, Fry JC (2003) Elevated abundance of bacteriophage infecting bacteria in soil. Appl Environ Microbiol 69:285-289

Berchieri A, Lovell MA, Barrow PA (1991) The activity in the chicken alimentary tract of bacteriophages lytic for Salmonella typhimurium. Res Microbiol 142:541-549

Biswas B, Adhya S, Washart P, Paul B, Trostel AN, Powell B, Carlton R, Merril CR (2002) Bacteriophage therapy rescues mice bacteremic from a clinical isolate of vancomycin-resistant Enterococcus faecium. Infect Immun 70:204-210

Bogovazova GG, Voroshilova NN, Bondarenko VM (1991) The efficacy of Klebsiella pneumonia bacteriophage in the therapy of experimental Klebsiella infection. Zh Mikrobiol Epidemiol Immunobiol 4:5-8

Bogovazova GG, Voroshilova NN, Bondarenko VM, Gorbatkova GA, Afanaseva EV, Kazakova TB, Smirnov VD, Mamleeva AG, Glukharev IA, Erastova EI, Krylov IA, Ovcherenko TM, Baturo AP, Yalsyk GV, Arefyeva NA (1992) Immunobiological properties and therapeutic effectiveness of preparations from Klebsiella bacteriophages. Zh Mikrobiol Epidemiol Immunobiol 3:30-33

Boon N, Goris J, De Vos P, Verstraete W, Top EM (2001) Genetic diversity among 3-chloroaniline- and aniline-degrading strains of the Comamonadaceae. Appl Environ Microbiol 67:11071115

Boon N, De Windt W, Verstraete W, Top EM (2002) Evaluation of nested PCR-DGGE (denaturing gradient gel electrophoresis) with group-specific $16 \mathrm{~S}$ rRNA primers for the analysis of bacterial communities from different wastewater treatment plants. FEMS Microbiol Ecol 39:101-112

Borsheim KY (1993) Native marine bacteriophages. FEMS Microbiol Ecol 102:141-159

Chanishvili N, Chanishvili T, Tediashvili M, Barrow PA (2001) Phages and their application against drug-resistant bacteria. J Chem Technol Biotechnol 76:689-699

Chernomordik AB (1989) Bacteriophages and their therapeutic prophylactic use. Med Sestra 6:44-47

De Boever P, Wouters R, Vermeirssen V, Boon N, Verstraete W (2001) Development of a six-stage culture system for simulating the gastrointestinal microbiota of weaned infants. Microb Ecol Health Dis 13:111-123

De Gheldre Y, Struelens MJ, Glupczynski Y, De Mol P, Maes N, Nonhoff C, Chetoui H, Sion C, Ronveaux O, Vaneechoutte M (2001) National epidemiologic surveys of Enterobacter aerogenes in Belgian hospitals from 1996 to 1998. J Clin Microbiol 39:889-896

Ewert DL, Paynter MJB (1980) Enumeration of bacteriophage and host bacteria in sewage and the activated sludge treatment process. Appl Environ Microbiol 39:576-583

Falkiner FR (1992) Enterobacter in hospital. J Hosp Infect 20:137140
Flynn DM, Weinstein RA, Nathan C, Gaston MA, Kabins SA (1987) Patients' endogenous flora as the source of "nosocomial" Enterobacter in cardiac surgery. J Infect Dis 156:363-368

Fryklund BA, Tullus K, Burman LG (1994) Association between climate and Enterobacter colonization in Swedish neonatal units. Infect Control Hosp Epidemiol 14:579-582

Furuse K, Osawa A, Kawashiro J, Tanaka R, Ozawa A, Sawamura S, Yanagawa Y, Nagao T, Watanabe K (1983) Bacteriophage distribution in human feces - continuous survey of healthy subjects and patients with internal and leukemic diseases. J Gen Virol 64:2039-2043

Galili D, Donitza A, Garfunkel A, Sela MN (1992) Gram-negative enteric bacteria in the oral cavity of leukemia patients. Oral Surg Oral Med Oral Pathol Oral Radiol Endod 74:459-462

Gaston MA (1988) Enterobacter: an emerging nosocomial pathogen. J Hosp Infect 11:197-208

Gautier M, Rouault A, Sommer P, Briandet R (1995) Occurrence of Propionibacterium freudenreichii bacteriophages in Swiss cheese. Appl Environ Microbiol 61:2572-2576

Griffiths RI, Whiteley AS, O'Donnell AG, Bailey MJ (2000) Rapid method for coextraction of DNA and RNA from natural environments for analysis of ribosomal DNA- and rRNA-based microbial community composition. Appl Environ Microbiol 66:5488-5491

Hack A, Selenka F (1996) Mobilization of PAH and PCB from contaminated soil using a digestive tract model. Toxicol Lett 88:199-210

Hambly E, Tetart F, Desplats C, Wilson WH, Krisch HM, Mann NH (2001) A conserved genetic module that encodes the major virion components in both the coliphage T4 and the marine cyanophage S-PM2. Proc Natl Acad Sci USA 98:11411-11416

Heid CA, Stevens J, Livak KJ, Williams PM (1996) Real time quantitative PCR. Genome Res 6:986-994

Jalaluddin S, Devaster JM, Scheen R, Gerard M, Butzler JP (1998) Molecular epidemiological study of nosocomial Enterobacter aerogenes isolates in a Belgian hospital. J Clin Microbiol 36:1846-1852

Jensen EC, Schrader HS, Rieland B, Thompson TL, Lee KW, Nickerson KW, Kokjohn TA (1998) Prevalence of broad-hostrange lytic bacteriophages of Sphaerotilus natans, Escherichia coli, and Pseudomonas aeruginosa. Appl Environ Microbiol 64:575-580

Josephsen J, Neve H (1998) Bacteriophages and lactic acid bacteria. In: Salminen S, Wright A (eds) Lactic acid bacteria: microbiology and functional aspects. Dekker, New York, pp 385-436

Kowalchuk GA, Bodelier PLE, Heilig GHJ, Stephen JR, Laanbroek HJ (1998) Community analysis of ammonia-oxidising bacteria, in relation to oxygen availability in soils and root-oxygenated sediments, using PCR, DGGE and oligonucleotide probe hybridisation. FEMS Microbiol Ecol 27:339-350

Kucharewicz-Krukowska A, Slopek S (1987) Immunogenic effect of bacteriophage in patients subjected to phage therapy. Arch Immunol Ther Exp 5:553-561

Macfarlane GT, Macfarlane S, Gibson GR (1998) Validation of a three-stage compound continuous culture system for investigating the effect of retention time on the ecology and metabolism of bacteria in the human colon. Microb Ecol 35:180-187

Mammeri H, Laurans G, Eveillard M, Castelain S, Eb F (2001) coexistence of SHV-4- and TEM-24-producing Enterobacter aerogenes strains before a large outbreak of TEM-24-producing strains in a French hospital. J Clin Microbiol 39:2184-2190

Middelboe M (2000) Bacterial growth rate and marine virus-host dynamics. Microb Ecol 40:114-124

Minekus M, Smeets-Peeters M, Bernalier A, Marol-Bonnin S, Havenaar R, Marteau P, Alric M, Fonty G, Veld J (1999) A computer-controlled system to simulate conditions of the large intestine with peristaltic mixing, water absorption and absorption of fermentation products. Appl Microbiol Biotechnol 53:108-114 
Molly K, Vande Woestijne M, Verstraete W (1993) Development of a 5-step multi-chamber reactor as a simulation of the human intestinal microbial ecosystem. Appl Microbiol Biotechnol 39:254-258

Ramesh V, Fralick JA, Rolfe RD (1999) Prevention of Clostridium difficile-induced ileocecitis with bacteriophage. Anaerobe 5:69-78

Sambrook J, Russell DW (2001) Molecular cloning: a laboratory manual, 3rd edn. Cold Spring Harbor Laboratory Press, Cold Spring Harbor, N.Y.

Sanders WE, Sanders CC (1997) Enterobacter spp: Pathogens poised to flourish at the turn of the century. Clin Microbiol Rev 10:220-241

Slopek S, Durlakowa I, Weberdabrowska B, Kucharewiczkrukowska A, Dabrowski M, Bisikiewicz R (1983) Results of bacteriophage treatment of suppurative bacterial infections.1. General evaluation of the results. Arch Immunol Ther Exp 31:267-291
Slopek S, Weber-Dabrowska B, Dabrowski M, KucharewiczKrukowska A (1987) Results of bacteriophage treatment of suppurative bacterial infections in the years 1981-1986. Arch Immunol Ther Exp 35:569-583

Smith HW, Huggins MB (1983) Effectiveness of phages in treating experimental E. coli diarrhoea in calves, piglets, and lambs. J Gen Microbiol 129:2659-2675

Soothill JS (1992) Treatment of experimental infection of mice by bacteriophage. J Med Microbiol 37:258-261

Sulakvelidze A, Alavidze Z, Morris JG (2001) Bacteriophage therapy. Antimicrob Agents Chemother 45:649-659

Summers WC (1999) Félix d'Herelle and the origins of molecular biology. Yale University Press, New Haven

Yoon SS, Barrangou-Poueys R, Breidt FJ, Klaenhammer TR, Fleming HP (2002) Isolation and characterization of bacteriophages from fermenting sauerkraut. Appl Environ Microbiol 68:973-976 